\title{
The Genealogy of Banyumas Film: From Street to Screen
}

\author{
M. Taufiqurrohman, A. Chusna \& L. Suzanna \\ Universitas Jenderal Soedirman, Purwokerto Indonesia. ORCID id: oooo-0oo3-0935-6516. \\ Email: taufiq_sombo@yahoo.com
}

Received October 15, 2017; Revised November 21, 2017; Accepted November 30, 2017; Published December o9, 2017.

\begin{abstract}
This paper mainly discusses the genealogy of Banyumas Film as a cultural product in the postNew Order era. Using Panginyongan language (a sub-Javanese language that has distinct features, what so-called "ngapak" dialect), Banyumas Film is known for bringing strong and definite issues into the screen. Ideologically, it resists the New Order legacies like the ideology of developmentalism that promotes urbanization, feudalism, corruption, military-based regime, etc. To gain the data, this research employs in-depth interview with two Banyumas filmmakers who are known as the pioneer of Banyumas Film production. By unpacking the life of the two figures, we can see genealogically how these young filmmakers play their important role not only as activists but also as cultural producers. They voice against their opposition to the New Order legacies through aspects of practice and discourse of filmmaking. Their films are greatly influenced by their experience as the exponents of 1998 activists.
\end{abstract}

Keywords: Banyumas Film, genealogy, 1998 activists, New Order legacies.

\section{Introduction}

Film played a very historic role in the making of New Order regime. The regime wittingly used film as well as other popular cultures to legitimate its political power. Budi Irawan quoted Salim Said (Irawan, 1999, p.98) stating that there are at least two major ideologies of New Order that affect films: militarism of "historical military films" and developmentalism of "development film". Indonesian people have already consumed these kinds of cinematic ideology for more than three decades. As a result, the ideology of New Order has already been an integral part of most of the Indonesians' views. Therefore, any discourse about post-New Order films, including Banyumas film, should be located within the particular historical context of the New Order's cinematic legacies.

This research discusses the early historical development of Banyumas film within the context of the post-New Order Indonesia. The genealogical reading is applied to unpack how Banyumas film as a part of Indonesian short-films was ideologically constructed by some active cultural agents. Some researchers have analyzed elsewhere about the Indonesian independentshort films, but specific preliminary researches on outside Jakarta films have been relatively rare. Some scholars tend to emphasize in exposing only "Jakarta films" that achieved global fame in international festivals as their research object. Tilman Baumgartel (Baumgartel, 2011), for example,

(C) AesthetixMS 2016. This Open Access article is published under a Creative Commons Attribution Non-Commercial 4.0 International License (http://creativecommons.org/licenses/by-nc/4.0/), which permits non-commercial re-use, distribution, and reproduction in any medium, provided the original work is properly cited. For citation use the DOI. For commercial re-use, please contact editor@rupkatha.com. 
mentioned some Indonesian independent-short films in his article on independent films from South East Asia. He specifically mentioned three independent filmmakers; Riri Riza, Nia Dinata, and Edwin. All of them are Jakarta-based filmmakers who permanently live and work in Jakarta. In addition, the issues they uncover in their films are mostly "urban-Jakarta-ism" that has led them to achieve international fame. In this case, any detail about the local films in Indonesia was totally absent in Baumgartel's research.

More importantly, critical study about local films is very significant in order to examine one of the most crucial agenda of reformation, i.e. decentralization. In the context of post-New Order, the new republic tried to decentralize any power from the center (Jakarta) to the peripheries (outside Jakarta). This agenda ought to be manifested not only in the field of politics and economics but also in the field of culture. Decentralization in culture means that any policy or gesture about "national culture" should not be fully controlled from Jakarta as if Jakarta is the most ultimate cultural setter. Jakarta should be positioned as one among other various culture setters in Indonesia. This kind of decentralized view also occurred in the field of film. Another film critic, Katinka van Heeren actually has initiated research on independent-short films in Indonesia, including local films. However, her explanation, as well as data taken, was still dominantly telling about Jakarta-based films. At the time of Baumgartel, however, local films were not totally absent. Some local films and the filmmakers were shortly mentioned. Among those filmmakers and their films were two pioneers of Banyumas film: Dimas Jayasrana and his film entitled Kepada Yang Terhormat: (To The Esteemed:) and Bowo Leksono with his Peronika.

The rise of local films, including Banyumas film, was part of that ideological movement to decenter cultures. Consequently, filmmaker communities, especially the independent ones, treated Jakarta films and non-Jakarta films like Banyumas film equal. Thus, both Jakarta and nonJakarta filmmakers have the same opportunity to promote and negotiate their cultural vision to their audience in the public sphere named Indonesia. This makes any study about local films crucial for the films serve as cinematic portraits of ordinary phenomena of decentralization, be it exposed wittingly or unwittingly. This article will thus complete the existing fine research on Indonesian independent-short films. So, in order to accomplish this untouched particular field of study and to fully understand about post-New Order Banyumas film, genealogical reading hopefully helps us find some new insights.

By genealogy, we mainly refer to Michel Foucault's definition of "genealogy" as "One has to dispense with the constituent subject, to get rid of the subject itself, that is to say, to arrive at an analysis which can account for the constitution of the subject within a historical framework. And this is what we call genealogy" (Clifford, 2001, p. 7). Clifford further explains Foucault's genealogy by contrasting genealogy from metaphysics. If metaphysical study tends to find the essence of subject by questioning "What are the political subjects?", genealogical study, in contrast, questions "How are political subjects formed?". While the former tries to search the essence of political subjectivities, the later inquires into the contingent historical conditions of political subjects. Based on this theoretical framework, we try to uncover the genealogy of Banyumas film (as part of post-New Order film) as "political subjects" which were formed in a very particular historical context. Thus, the question of "What is Banyumas film?" is not relevant to this paper. Instead, we formulate the research question into "How is Banyumas film formed?". Furthermore, this paper tries to challenge the metaphysical essence of Banyumas film by exposing more about the socio-political context of its birth- the New Order and its cinematic legacies. 


\section{Military Historical Films and Development Films}

During the New Order, some Indonesian films were purposely produced to glorify the role of military struggle over the diplomatic-civilian movement. Moreover, some films were produced mainly to propagate heroic legacy of only one military figure, President General Soeharto. Of three films analyzed by Irawan, two films Janur Kuning (Yellow Young Coconut Leaf) and Serangan Fajar (Attack at Dawn) promulgated Soeharto's heroism in the national struggle against Dutch colonization. This cinematic apparatus helped Soeharto continue his reign for almost thirty-two years. Irawan (1999, p. 178) further stated that "sinema Indonesia tidak hanya terbatas sebagai medium hiburan, tetapi sekaligus menjadi medium hegemoni militer. Melalui film-film yang diklaim oleh pemerintah (Orde Baru - ed) sebagai "film sejarah" - keunggulan militer atas sipil sengaja direproduksi". Thus, Indonesian cinema functions not only as a medium of entertainment but also of military hegemony. Through film, claimed by New Order government as a historical film, the superiority of military over civilian was intentionally produced.

The hegemony of military regime cannot be separated from another ideology of New Order; developmentalism. Unlike President Soekarno who protected national natural resources from foreign investment, Soeharto welcomed free market and foreign investment. Soon after Soeharto took up the reign, many multinational corporations (especially from the USA and its allies) invested in the natural resources industry, such as gas, oil, gold, and so on. To maintain the connection of this big industry, protection was needed from the military regime. This connection was controlled by top army leaders who gave their total loyalty to the one and only supreme leader, President General Soeharto. For example, one of the national oil factories controlled by the military was Pertamina. Although, now it is officially under ministry control, until 1975 Pertamina was solely controlled by military elites (Irawan, 1999, p. 178). Beside this ministrymilitary connection, military elites also allied with the Chinese conglomerates and foreign investors. What they got from this connection was a large amount dirty money from import license, contract, concession, bank credit, monopoly right, etc. Under those circumstances, in the name of development, corruption had become a part of the New Order's bequest.

Theoretically, developmentalism is rooted from the theory of modernization. This theory sees development as an evolutionary process of a human being from traditionalism to modernism. Traditionalism that is identical with any values, norms, and ways of life from "Third World countries", is constantly considered as a problem. While modernism, which means any progress of the West after industrial revolution-rationalism, positivism, natural sciences, Eurocentrism, industrialization, neoliberalism, and exploitation of natural resources, is always considered as the only way to solve the problems of a human being around the world from hunger, poverty, uneducatedness, etc. (Fakih, 2012, p.47). Furthermore, this theory assumes that people should live in a global village so that globalization is needed. According to supporters of developmentalism, globalization is the process where all people throughout the world have no other alternative or choice to pursue their happiness, success, and welfare other than through modernism or developmentalism. This biggest myth is created by the West to manipulate or "hegemonize" (using Gramsci's term).

Based on the theoretical framework, the New Order was a perfect model of developmentalism to its devotees. In Indonesia, this ideology was established academically by a regime of economics namely "Berkeley mafia" (US-university-linked scholars). Besides, it was also maintained militarily by Army elites. This coalition between the "professors' and the "generals" made it so hegemonic that it led to construct a new face of Indonesia as a postcolonial nation. 
For the most part, developmentalism has become one of the main keys to unpack the legacies of New Order and its impacts on social, economic, political as well as cultural life.

Krishna Sen stated, "Films in this genre (development film) epitomized the political strategy and vision of the New Order government, which was based on the encouragement of economic development and modernization" (Heeren, 2012, p.85). Heeren also mentioned that this kind of genre was particularly developed during Ali Moertopo's term of office as Minister of Information (1978-1983). During his era, the Dewan Film Nasional (DFN, National Film Council) forced the idea that film should portray 'the struggle of scientists, technocrats, and others to improve the prestige of the nation'. Furthermore, in film pembangunan (developmental film) the focal characters were heroes; but now the protagonists who were heroes of development, came to the village to teach the local, traditional people how to become modern, to trust the national government, and to distrust the villain, usually represented by local, traditional, spiritual leaders or shamans (Heeren, 2012, p. 85). Thus, it is safe to say that the New Order used films to construct negative images of local-traditional communities. The films directed primary cinematic doctrine to Indonesian viewers that to be a modern nation means to renounce local wisdom and traditionalism. To put it another way, to be the protagonist of the nation one should be a modern as to be a traditional means to be the antagonist of the nation. This production of cinematic doctrine was very effective in spreading out New Order's developmentalism. Moreover, the New Order made a special mode of film distribution that was so-called "layar tancap or layar tanjleb" (screening films by mobile cinemas which traveled from one village to another).

Looking at Indonesia and its cinematic world as discussed above, we see how cinema was effectively used to blow out the New Order's values and ideas, especially relying on developmentalism. It was profoundly obvious that developmental films within developmentalism framework had already printed dark legacies in the body of the nation. This made developmental films became the main object of criticism from anti-New Order parties, like activists, students as well as filmmakers. The fall of the New Order in 1998 opened new challenges. It signified a very dramatic transition in Indonesian cinema. Accordingly, many post-reform filmmakers have articulated their cinematic counter-attack against the New Order's developmentalism and its developmental films.

\section{Independent-Short Film in Indonesia: A Short Overview}

The rise of reform/post-reform films has been signified by the production of films which articulated different "taste" as well as the ideology of New Order's. As stated by Heeren (Heeren, 2012, p.85), the difference between the post-reform films and the New Order's lies in two levels: production level (using Heeren's term "practice") and content/issue level (Heeren's term "discourse"). In the practice level, the films were produced independently which means that the production was conducted without following official procedures created by New Order, like government's permission and censorship. While in the discourse level, the films explored issues that were previously prohibited (or at least not favored) by New Order, like shamanism, traditionalism, communism, anti-urbanization and local-issue-based films. Thus, these two levels of cinematic counter-culture lead the films the so-called film independen (independent film). The films are generally of short duration and not for commercial interest. Later the name of the films has evolved into film pendek (short film). 


\section{Independent-Short Films}

The independent-short film was actually not something new in Indonesian cinema. It was firstly introduced in 1970s-1980s, gaining very little attention from government, public and film communities themselves. The 1998 reform has brought new optimism to the advancement of short films. The new political condition has opened opportunities for filmmakers to produce their own sidestream or "independent" films. The term "independent" means that they do not depend on government and film industry to produce the films. The independent filmmakers have their $100 \%$ freedom to work out the production cost and the content of the film. Gotot Prakosa characterized the films into four points: 1) the films are produced with their own self-funding (mostly with very cheap cost), 2) the idea they explore is their original idea, 3) the films mostly have very short duration, and 4) the filmmakers ignore any official censorship (Prakoso, 2001, p.9).

Not only in production level, had the celebration of the independent film also occurred in exhibition level. For the first time after the reform, an Independent film festival entitled "Festival Film-Video Independen Indonesia" was held on 29-31 October 1999. This festival celebrated the creativity of young filmmakers who produced sidestreams or independent films. This festival became one of the historic events that made a big impulse to the movement of sidestream film.

In the middle of its development, the term "independent" was still found problematic to use. Some years after 1998 reform, most filmmakers preferred categorizing films they produced by duration only. They simply called the films "short films". The aim was to differentiate it from that conventional films that have a longer duration. The following dispute was about precise duration. Gotot Prakosa, for example, in his early book Ketika Film Pendek Bersosialisasi (Prakoso, 20o1) quoted Derek Hill's formulation in the 1950 s that the duration could not be more than 50 minutes. Later this formulation was renewed that resulted in some types of films naming: 1) spot film (between 10 to 60 seconds), 2) pocket film (50 seconds to 2 minutes), 3 ) short film ( 2 to 30 minutes), 4) medium length (30 to 50 minutes), and 5) film length film ( 50 to 2 hours or more). In his later book, Film Pendek Independen dalam Penilaian (Prakosa, 2005), Gotot Prakoso still used this formulation that the duration of a short film should not be more than 30 minutes.

Based on the historical background, this paper tries to unpack the phenomenon of Banyumas short films, as a part of post-New Order film movement at large. As "political subjects", this paper tries to uncover how Banyumas film also attempts to counter the New Order's cinematic legacies through the stories of its two pioneers: Dimas Jayasrana and Bowo Leksono.

\section{The Genealogy of Banyumas Film}

Banyumas film generally has a similar formula like other independent local films. The similarity lies in its practice and discourse that tend to break New Order's legacies. However, as a "political subject", Banyumas film lives and grows in a particular historical local context that makes it different and unique. The term Banyumas refers to name four regions in the central Java province: Purbalingga, Banyumas, Cilacap, and Banjarnegara. All regions share common characteristics. One of them is the language, namely panginyongan language (a sub-Javanese language that has distinct feature, what so-called ngapak dialect). Bringing up the case study of Dimas Jayasrana and Bowo Leksono, we try to see genealogically how Banyumas film with its unique nativities oppose the legacy of New Order's films, especially its censorship practice and ideology of 
modernization/developmentalism. The discussion will cover both the aspect of film practice and discourse.

\section{Dimas Jayasrana: New Technology, New Ways to Resist}

The rapid development of film technology was actually a global phenomenon. It happened not only in Indonesia but also in the "Third World" countries. In the particular context of Southeast Asia, Baumgärtel (2011) accurately depicted the above condition with this statement, "Different and distinct as the work of these film-makers is, this new generation has often been empowered by easy and cheap access to the digital video. The arrival of relatively affordable video cameras that allow for shooting in broadcast quality, editing software that runs on home computers, cheap DVD burners that allow film-makers to create their own DVD's and the Internet as a medium to either promote or even distribute one's work are the most important tools that have made this democratic cinema revolution possible in a part of the world that is otherwise not known for its democratic disposition." (p.58).

In 2001, two students of Universitas Jenderal Soedirman (Unsoed) Purwokerto made a documentary-experiment film entitled Kepada Yang Terhormat Titik 2 (To The Esteemed : ). They were Dimas Jayasrana and his boarding housemate, Bastian. Katinka van Heeren, an expert of Indonesian film studies, writes that historical event in her book Contemporary Indonesian Film: Spirits of Reform and Ghosts from the Past (2012). That film had its premiere on $18^{\text {th }}$ January 2002. It was later considered as the first Banyumas film. Produced three years after the reformation, the film depicts how common people tell about their government freely. This film generally shows the life of urban people in Purwokerto through the comments of street vendors, street children and also farmers. Thus, with or without this special notice from Katinka, it is commonly accepted that Dimas has a special place in the movement of Banyumas film for his significant legacies in the field.

Back to the end of 2oth century, this era was mainly signed with the rapid development of new technology, including film technology. As the young generation who lived in the era, Jayasrana experienced the transition of old technology to the new one. He saw this new technology as a miracle and at the same time as a site to resist (interview with Jayasrana). He could see other opportunities as well as challenges in the film world. This new development, as we can see in the following discussion, led him to create alternative ways of watching, screening and even producing film. Thus, tracing back of how Dimas conducted film screening and then producing his own films in Banyumas will help us see how political the new technology was. To put it in the context of post-New Order films, the new technology helped independent filmmakers, like Jayasrana, produce and exhibit films without following any official procedures (including censorship) from the government. In the context of Banyumas film, there are, according to Jayasrana, at least six new technologies that significantly brought new development not only in production and distribution stage but also in consumption. They are video, video projector, internet, pirated software, self-assembled computer, and camera.

\section{Video}

Nugroho and Herlina (2015, p.241) stated that video had become part of many Indonesians daily lives. Unlike film industry that had always worked out the cost of production, sidestream film communities had started to experiment with video. Since the video production was not for 
commercial (yet only for the sake of art and advocating), the cost of production and the benefits were not the issues. With these alternative videos, viewers could enjoy the movies without censors. Besides, they could arrange where and when to hold screening based on their own needs. Further, Nugroho and Herlina, quoting Hill, noticed that in the mid of 1980 os video and laser disc of foreign movies (that was actually banned by the official government) were getting easier to access. Indonesian middle class who frequently traveled abroad, like students, intellectuals, and cultural workers acted as cultural brokers. Thus, foreign video screening was easily held by the circle of Jakartans middle class. As the result, screening of uncensored films (most of them were documentary and newsreel) was quite often organized in the public spaces, like NGO buildings, and even advertised or postered in campus and public library.

In the 1990s, the presence of these foreign movies in Indonesia inspired some socialactivists to produce their own (documentary) videos. The aim was not to achieve some aesthetics level or to entertain people, but merely to advocate marginalized communities like sailors, students, kampong people, farmers, etc. They mainly used film to document important events that happened in the community. Besides, they used the film to be a media to investigate social problems as well as to offer solutions. A documentary film entitled Buka Sasi Lompa (1992, 1996, and 2007 version) is an instance of this kind of film. This film was facilitated by a civil rights activist, Roem Topatimasang and was considered as a pioneer of so-called film komunitas (community film) or film pembebasan (liberation film) that later became film independen (independent film). Following the "success" of this film, there were many other "film komunitas" produced. This made 1990's the birth era of community or independent film (Nugroho and Herlina, 2015, p.243). All of this development became accessible for non-film industry community because of new video technology.

During this particular context of film technology development, Jayasrana entered university. A student of social and politics faculty, he joined a theater unit "Si Anak" in 1998. Grown up as a teenager who loves watching movies, Dimas brought that hobby to the theater community. In 1999, he watched a movie, The Dead Poet Society, in his boarding house. Then he invited his theater friends to watch and discuss the movie. It was a very small group that consisted of only 2-4 members. They were Indra Upil, Syarif, Budi, and Yudhi. After watching several movies in the boarding house, they had the idea to hold movie screening in "Si Anak" headquarter. They thought that they could discuss not only on the movie, but also the elements of theater in the movie, like script, dramaturgy, etc. They theorized that movie was actually the fifth dimension of theater so that movie and theater should be freely combined with other disciplines of arts like photography, music, paintings, literature, and others. That thought led them to found a new sub-unit named Unit Pencinta Film (Film Lovers Unit) that was initiated by Indra Upil. This new unit became part of Si Anak divisions. The vision of the unit was that watching film was not only for entertainment but also, more importantly, for knowing scientific activity. For example, they screened for public a film from Brazil telling about the wretchedness of bureaucracy in the country. This screening had a big success in term of the number of the viewers. This attracted Fox, a candy factory, sponsoring the screening in campus hall. This sponsorship run twice.

In conclusion, in this Banyumas film development stage, happened only in UnsoedPurwokerto, the main activity was screening (including discussing) movies. Production of film had not been the issue yet. We can see that at this stage the new video technology made movie screening possible, not only for limited viewers but also for the public. This presence of public screening was much indebted to another new film technology- video projector. 


\section{Video Projector}

Another technology related to video was video projector. Other than video, it was another main tool for film screening. At that time, it was a very luxurious stuff that only a few people or institution owned. Jayasrana recalled that in the late 1990's the only projector available in Purwokerto-Banyumas was only having 500 ANSI lumen. It was very expensive for students to rent as the charge was Rp.150.ooo per hour. To compare, students' living cost for a month was Rp. 250.000. Jayasrana further stated that they should pay Rp 200.000 for one hour and a half. From this story, we can see how expensive the cost was so that it was hardly possible to hold screening without any sponsor.

\section{Internet}

When it came to the production of film, not only video technology but internet also played an important role. How did the internet work on that stage? Jayasrana told that internet became a new media that connected people around the world, including film people. According to him, the significant stage of the development of independent film was 1995 when internet had already been consumed by people doing film (though a very few party). It happened until 1997 when economic crisis happened leading to the resignation of Soeharto in 1998. There was a theory, Jayasrana added, that the fall of Soeharto and its New Order could not be separated from the role of internet. A very few of activist leaders of anti-Soeharto connected and organized the movement via internet. One of the references was Ayu Utami's novel. In one chapter, there was a story about a website for a hidden underground forum. Jayasrana claimed that it was factual as he himself ever met the real members of the forum in Jakarta.

Back to 1995, why did this year become so important? Jayasrana stated that people had started to use internet to communicate online in this year. In 1999, it had already been a public domain. This new development rapidly opened doors of information from around the world. There were two important features of internet; search engine machines and Yahoo Group mailing. The search engine machines were not as easy as those are of today's. The engines were only Altavista and Yahoo. Despite their weaknesses, people were excited to be able to access any kinds of information. It was really worth at that time to find such alternative sources of information. People could freely access information that was impossible to find in mainstream media. For example, Dimas found two articles on Indonesian films, translated into English, that were really useful as his frame of reference to explore the problem of film development in Banyumas, especially in Purwokerto. By showing this global connectivity via internet, Jayasrana wanted to say that there was actually nothing too unique or too particular in the development of Banyumas film as sidestream film. As a part of the global film, Banyumas film lived in a global village where connectivity via internet had united people, as well as their ideas. This connectivity was getting easier to access in Banyumas when WaksantaraNet (one of Telkom-affiliated) started the business and made bombings of an internet cafe in the early 2000 .

Another feature of internet that helped people communicate online was Yahoo Group for mailing. Jayasrana further stated that there were many mailing lists at that time, but one that had the biggest member was "film forum". During 2000 to 2003, there were 1200 members with more or less 700 of them were very active. They came from many regions. From this mailing list, filmmakers exchanged information about film. Jayasrana also recalled that he could connect his virtual filmmaker friends from this mailing list. Moreover, he learned how to edit film from this site. When he encountered a problem in film editing, he would ask members of the group. He 
remembered his virtual friend, Danung Nugraha, the then-member of cinema club at Universitas Muhammadiyah Yogyakarta, whom he had invited to come to Yogyakarta to learn editing. This personal experience of Jayasrana shows that Yahoo Group mailing list has played a very significant role in linking filmmakers and their communities to cooperate with each other.

In short, it is safely said that internet was another new technology that made sidestream films possible to produce, including Banyumas film. In Yahoo Group mailing, for example, people could freely state their mind about not only film but also politics without hesitation or fear. The discussion could not be controlled or intervened by the state or government. This new mode of film production showed us how political the role of this new technology was since it directly or indirectly led the sidestream filmmakers to break New Order's cinematic legacy.

\section{Self-Assembled Computer and Pirated Software}

Another new technology was computer. To be more specific, it was self-assembled computer. According to Jayasrana, computer actually revolutionized "the Third World", including Indonesia because, for the first time, computer became a technology that could be used by the middle class. Before the 1990's, computer was very expensive that only a few elite of upper class could have and use it. Since pirated software was required to operate a self-assembled computer, Jayasrana claimed that no filmmakers from the 1990 generation did not pass through this stage of pirated software. This was the situation because the price of original software for editing, video processing, and others was very expensive. He also admitted that he learned and has succeeded to become a film editor because of the self-assembled computer and pirated software. It is necessary to fetch lines from Gotot Prakosa's note (2005):

"Ketika ditanya soal software apakah itu orisinal atau aspal, mereka hanya nyengir saja, kemungkinan memang bajakan. .. Hal ini dikarenakan biaya software orisinal itu tidaklah murah dan cukup berbelit untuk mendapatkannya, sementara software aspal yang sudah bisa dipakai belajar dan memproduksi satu keping VCD yang berisi lebih kurang 20 software harganya kurang lebih Rp. 25 ribu di Glodog atau Mangga Dua, Jakarta. Juga bisa didapat di Yogya dengan harga sedikit lebih mahal dibandingkan di Jakarta. Namun tetap harga yang sangat murah untuk segebog perangkat lunak."(p.74)

(When asked about whether the software was original or pirated, they (independent filmmakers) just laughed indicating it was pirated... The price of the original software was too expensive and also difficult to find. On the other hand, the price of the pirated one that could be used to learn and produce one VCD and that also consisted of 20 softwares, was only less than IDR 25000 in Glodog and Mangga Dua, Jakarta. It was also available in Yogya though more bit expensive than Jakarta's price. But still a very affordable price for those plentiful softwares).

This particular condition of the development of new technologies made the production of films, especially independent films, possible. Jayasrana recalled his memory of his early career as a film producer in 2000. He edited his first film, Kepada Yang Terhormat Titik 2 (To The Esteemed: ) with the self-assembled computer and pirated software. As stated above, not only Jayasrana but also most of the filmmakers at that time used the pirated software. This condition was supported by the fact that this practice was allowed or accommodated in independent film festivals, be it local or national. For example, as Prakosa further stated (Prakosa, 2005) that the pirated software of Adobe Premiere was used for editing by most of the participants from Jakarta and other 
provinces. That was the fact from the practice stage of Indonesian short-independent films. It can be said that pirated software and self-assembled computer became the main tool to resist New Order's film legacy for the early generation of post-New Order Indonesian filmmakers.

\section{VCD}

Another pirated technology was Video Compact Disc (VCD). With this pirated technology, Jayasrana admitted that his film literature improved significantly for he could watch movies that were not screened in the mainstream theaters in Indonesia. This stage, according to him, was the milestone of the development of independent film. Jayasrana's argument was in line with Bäumgartel's enquiry (2012:31):

"Therefore, video piracy that is rampant in most countries in the region was instrumental in bringing international art-house and world cinema into the countries of South East Asia. The importance of piracy (that, of course, is illegal in all the countries of the region) in developing film appreciation and media literacy in Southeast Asia cannot be overstated, and many filmmakers have openly acknowledged their indebtedness to pirated films in their development. While Amir Muhammad has quipped that 'piracy has been such a valuable teacher to us', Khavn de la Cruz, whose own work is full of references to international horror and trash cinema, says: 'Thanks to piracy, local movie-lovers have more options, thus broadening their taste. Some even say that video piracy is creating a cultural revolution in film-viewing in the Philippines'.

This evidence showed that in the broader context of the new development of independent films in South East Asia, video piracy had already been a common phenomenon. The variance lied in the social and political context of each country that made independent filmmakers respond differently. For most of the Indonesian independent filmmakers, for example, the pirated technology was used to articulate sidestream films that directly or indirectly resist New order's film legacy.

\section{Camera}

Another technology that developed independent film was camera. At that time, handy camera (handycam) was a miracle that made film possible for "non-film people". But it was still expensive at that time that only a few could have it. When eventually Jayasrana came to produce his film, it happened by coincidence. At that time, camera was not for rent, it was only for private use. Jayasrana recalled that the only person who was identified having a camera in Banyumas was Bambang E, an ex-reporter of RCTI (the oldest private TV station). Until one day, his friend, Alex, asked him if he still wanted to make a film. Jayasrana said absolutely yes, he always wanted to, but the problem was camera. Alex asked him to meet a senior, Anang, who coincidently visited Purwokerto from Semarang. This senior brought with him a handycam. The following story was that Anang lent his camera to Jayasrana for two days and a half. Too many ideas came to his mind, Jayasrana brought the camera to his boarding house. With his friend, Bastian, he then decided to choose a recent trending topic at that time to depict, and that was the impeachment of President Abdurrahman Wahid (a.k.a. Gus Dur). That was the history of Kepada Yang Terhormat Tititk 2 (To The Esteemed: ), the first film produced in Banyumas. 


\section{Bowo Leksono: The Rise of Anti-Development Local Film}

Leksono was an exponent of 1998 activist. In 1998, he was a student of law at Universitas Diponegoro (Undip), Semarang, Central Java. He entered Undip in 1996 and graduated in 2000. As a student activist, he was the member of Theater Group "Themis". As a theater member, he also enjoyed independent films outside the campus. Leksono recalled that at that time there were some independent films produced by Indonesian NGOs. Although most of them were documentary, students at that time were very excited to watch those kinds of film for there was no other alternative. The only mainstream films produced were market-oriented films and New Order films. Therefore, the presence of these sidestream films before 1998 movement brought many advantages for student-activists because of its anti-mainstream discourses.

During the 1998 movement, he and his theater made performance art as a part of students' demonstration. They performed not only in the campus but also outside the campus. When the reform movement came to its climax, they held performance not only in Semarang but they also went to Jakarta. They joined students doing demonstration from all parties. Leksono recalled his memory in May 1998. He and his Undip friends were part of students' demonstration against the brutality of the military in Jakarta. After the fall of Soeharto and its New Order, in 2000 he finally graduated from Undip. Becoming jobless for one year after his graduation, he then migrated to Jakarta in 2001. He became a journalist in a national right-newspaper, Republika. He worked there for almost two years and a half (one year as a trainee and one and a half year as a full employee). His most important experience in Republika was when he worked for "Culture" desk. This desk made him familiar with the cultural performances held in some cultural centers, including film screening. Every Monday he, as a journalist, was always invited to watch mainstream movies for special premiere screening in theater before the movies' release. He then made a kind of release or news of the screened movies. Besides, he was also invited to watch side-stream movies in some alternative cultural centers in Jakarta, like Goethe Institute, Taman Ismail Marzuki (TIM), Teater Utan Kayu, etc. This experience of becoming a "culture" journalist in Jakarta later gave a very big influence on his career as a filmmaker. This profession made him familiar with many sidestream "Jakartan filmmakers" (those who live and produce films in Jakarta).

In 2003, Leksono was fired due to an internal political dynamic within Republika. He got IDR 25 million as severance pay. As a young journalist, the money was the smallest compared to senior journalists. Some of them got one hundred million, even half a billion. After that, he tried to survive in Jakarta and find some new jobs. However, after finding some new jobs, he decided not to fully live in Jakarta. The characteristics of his new project-based jobs made him flexible to manage his time by constantly shuttling back and forth between Jakarta and Purbalingga (his kampong). He could spend four months in Purbalingga and another four months in Jakarta. While Jakarta was the place where he earned money, Purbalingga became the place where he spent his money for developing Purbalingga film. He not only produced his self-funded films but also funded for film festival. He did this until 2010 when eventually he decided to go back and live in Purbalingga permanently.

As it was previously stated, his experience as "culture" journalist was his only early resources to produce films in Purbalingga. With this journalistic experience, he decided to produce his first film in 2004. To produce a film requires at least three things: a team (crew), equipment (camera) and a story. To begin with the team, Leksono asked his childhood friends and members of theater club "Topeng". He founded this club in 1994 when he was still a student. His early films, Orang Buta dan Penuntunnya (The Blind Man and His Companion) and Peronika, were produced with this community. As a result, the characteristics of the films were very 
theatrical as they just transferred theatre into screen. Besides, they did not have any experience in handling a film production. The second thing was a camera. At that time, camera was so expensive that only people with more money could buy. In an interview with cinemapoetica.com (April 13, 2014), Leksono recalled that his first analog camera (cost for Rp 1.5 million) was bought with his last payment from Republika. With this historic camera, he produced Orang Buta dan Penuntunnya. The last was the story. As he did not have any story to tell and did not know how to make a scenario, he filmed Ahmad Tohari's short story Orang Buta dan Penuntunnya. He adapted the story into the screen just like the way he adapted stories into a theater stage. The only major difference was the medium.

Why did he choose Ahmad Tohari? According to him, Tohari's stories were the most representative voices of Banyumas people, especially about their social-cultural life. In his following films, like Peronika, Gajian (Payday), and Senyum Lasminah (Lasminah's Smile), he tried to make his own stories about his people (Purbalingga-Banyumas people) just like the way Tohari narrated his short stories. At any rate, Leksono's films (and also some other Purbalingga films) were the cinematic versions of Tohari's short stories. In a personal communication, Leksono admitted the big influence of Tohari's works in his films. Not only in his production, he also made reading Tohari's works compulsory for those who learned and produced films under his supervision. It was a very common phenomenon that at that era young artist like Leksono was greatly influenced by an established author like Tohari. In the 2ooos, Tohari has already been one of the greatest senior Indonesian novelists. In fact, both Tohari and Leksono come from the same cultural biography, i.e. Banyumas. They speak in the same language and dialect, Bahasa Panginyongan (a sub-language of Javanese language). Besides, they shared the same experience of migrant worker as journalists in Jakarta. Even more, they had the same experience of going back to their kampong halaman, Banyumas, and permanently living there after experiencing Jakarta.

Leksono's decision to produce films in Purbalingga rather than in Jakarta was due to a practical and strategic reason. In an interview with cinemapoetica.com (Yusuf, 2014), he stated that producing film in Jakarta required many compromises. Besides, there were IKJ students and other filmmakers who had already been established players. This would make a very hard-hitting for him to compete with them. For this reason, he, although from 2003 to 2010 lived in Jakarta, not only produced his films in Purbalingga but also explored as well as exposed Banyumas culture very distinctively in his films. This distinctive characteristic made his films easily recognized by national short films milieu. Moreover, the films achieved many awards in the national festivals. Above all, Leksono's films have successfully built the strong foundation of Banyumas films (especially Purbalingga films). That was, according to us, the most important legacy of Bowo Leksono's films.

From the creative process of Leksono, we can learn how fluid yet ambiguous the connection between Jakarta as the center and Banyumas (Purbalingga) as the periphery was. In the level of Leksono's film production, Jakarta played a very important role. Leksono got his first experience and link with film communities in Jakarta. In term of economy, Jakarta also gave him money, not only to buy his first analog camera but also to fund production cost. In the level of exhibition, he, with his money from Jakarta, also funded for film festival named Parade Film Purbalingga (Purbalingga Film Parade). Later the festival has evolved into Festival Film Purbalingga (Purbalingga Film Festival). Without his Jakarta money, it was almost impossible to hold such a kind of big film festival. In the level of distribution, national festivals that are usually Jakarta-based have often invited his films to be screened publicly in their events. Jakarta also 
supported and promoted the films by giving them awards in some prestigious festivals. This distribution made his films easily recognized and got his broader audiences.

This Jakarta-Purbalingga link has also been antagonistic, especially in term of the film content or discourse. Most of Leksono's films show how unfriendly the connection between Jakarta and Purbalingga was. Jakarta and anything related to big cities tended to be seen as the antagonist, while Purbalingga and anything related to rural-kampong like tradition, costumes, arts, etc., was generally constructed as the protagonist. Most of Leksono's films strongly criticized the culture of urbanization in Jakarta and other big cities. Jakarta, as the representation of the center of the nation, promoted people to do urbanization; Purbalingga, as represented in some main characters, clearly opposed the idea of urbanization. This dominant discourse of antiurbanization can be seen as Leksono's ideology of anti-developmentalism for urbanization which was the cultural product of New Order's developmentalism. This anti-developmentalism can be obviously seen in Leksono's short films, especially in Peronika and Senyum Lasminah.

\section{Peronika}

Rural people's poverty and urbanization become central issues in Leksono's films. One of his films that narrates the issues is Peronika (2004). The original title of the film was Gara-Gara Henpun (Because of a mobile phone/ personal communication). Although the main theme of the film is about rural people's technological incompetence, the film, at the same time, unwittingly narrates the portrait of their poverty. It can be seen from the characters and the settings. The main character is Parno, a rural person who migrates to the capital, Jakarta, in order to find a better job. He left his wife, Jamilah or Si Jam, with his father at home. It should be done because of their poverty. In addition, the poverty can also be seen from the house setting. In one scene, the wife is depicted cooking in a very poor kitchen. Besides, the wall of the house is made from gedhek (bamboo craft) that indicates their terrible financial situation.

As stated above, another main issue of the film is about the technological gap between the rural and the urban life. Parno, as a migrant worker in the metropolitan Jakarta, already uses a mobile phone while his rural father did not know about the new technology. This reflects how any recent progress or development in technology was always concentrated in big cities like Jakarta. It was generally accepted that in term of access to new technology rural people were always left behind. This phenomenon also shows us the common knowledge about the gap of extremely economic growth between the "centers" of the nation (like Jakarta and other big cities) and the peripheries (like Banyumas and other regions).

Outside the screen, another story about the gap of technology occurred. When this film was nominated in Global Indie Film Festival (GIFF) Award 2005, held and broadcasted by Global TV station, it grasped good response as well as viewers' support in the form of Short Message Service. Many viewers from Aceh and Riau supported this film. Ironically, only few Purbalingganese, their respective neighbors, responded it positively due to poor TV signal connection, i.e. Global TV in the region. (Peronika Masuk Nominasi Giff Award, 2005).

As a matter of fact, this historic film is claimed as the first Banyumas film that uses Bahasa Jawa Panginyongan (a sub-language of Javanese language). Leksono said that Peronika was purposefully made to reflect as close as possible about Banyumas culture-from characters, characterization, setting, music illustration, and also dialect. He also stated that although the production cost was very cheap (that is only $\mathrm{Rp}$ 100000), the film had already achieved good 
appreciations from short film society. In term of public screening, the film had been screened for public in many places. In addition, it was also participated and got some awards in many film festivals like Festival Film Indonesia 2004 (Indonesian Film Festival, the biggest annual film festival in Indonesia), Global Indie Film Festival (GIFF) 2005, the Best Story in Sulasfifet 2005, and the Best Nominee in Mafviefest 2006 (Pergelaran CLC Terbentur Birokrasi, 2006).

Above all, the achievement of Peronika in many national festivals proves that Banyumas films as local-rural films were able to compete with other urban-films produced by filmmakers from big cities. This possibly happens because of the universal language of film that tends to expose a shared experience of the humanities. By the same token, Bowo said, "Although rooted in Banyumas culture, my films could be enjoyed by people outside Banyumas. It was because the films as media have universal language" (Kasting Terbuka di Purbalingga, 2005).

\section{Senyum Lasminah (Lasminah's Smile)}

Not only men like Parno in Peronika, many rural women also migrated to Jakarta. In Senyum Lasminah (Leksono, 2005), there is Surti, a rural woman character who is really obsessed with Jakarta. The story tells that she goes back home from Jakarta and tells her neighbors, including the main character of the film, Lasminah, about her "success" in Jakarta. When she meets with Lasminah, she repeatedly tries to sweet-talk her to migrate to Jakarta with her. She boasts that many women have already migrated to metropolitans like Jakarta and even gone abroad as overseas workers. They have all done it to get the big money that they do not get if they stay working at home. The story also narrates Surti as a rural poor girl who has excessively adapted some urban lifestyles, like language and fashion. First, when at home she chooses to speak Indonesian language (national language) mixing it with some urban slangs of Jakarta rather than using Javanese Panginyongan language (local language). She frequently uses addressing terms like "loe" or "lu" to say "you" and "gua" or "gue" to say "I". When she asks Lasminah, she says "Lu jadi ikut ke Jakarta"? (You come along with me to Jakarta, don't you?). She does it to emphasize her already "being Jakartans" as if to make a statement to her people- "I am no longer Purbalingganese." Another symbol was fashion. Surti makes her hair rebonding. It was a new hairdo trend in big cities at that time so that the curly hair could be straight. It happens to her as she gets lots of money from her job as a housekeeper. She tells Lasminah that hairdo costs Rp.2000oo, a very big money for only a hairdo to Lasminah and other rural girls. The ending of the film expresses the political statement of Leksono's ideology that Lasminah finally decides to keep staying and working at home as Batik home-artisan.

The story tells how Lasminah as a representative of the young rural generation objected to migrate to urban-Jakarta. This shows the ideology of anti-urbanization in Leksono's film. In one interview Leksono clearly stated that "I tried to blow out the endless social problem of rural youngsters who want to make a better life by instantly migrating to big cities. I do hope that the film could help them find a new perspective about urbanization (migrating to big cities). (Konflik abadi cara merubah nasib yang cenderung diidentikkan dengan hengkang ke kota inilah yang saya angkat. Saya berharap kisah ini menjadi bahan pertimbangan anak muda yang hendak ke kota untuk merubah nasib)". ('Senyum Lasminah' dari purbalingga Ikut FFI, 2005). To put it in the context of post New Order film legacies, this anti-urbanization can be seen as the counter-culture of local films to the mainstream ideology of New Order development film legacy that massively promoted urbanization and centralization of national wealth in Jakarta and other big cities. 


\section{Conclusion}

The analysis above shows how Banyumas film, as a part of new cultural products in post-New Order Indonesia, has been genealogically produced by the exponent of 1998 activists. Dimas Jayasrana and Bowo Leksono have become its two most prominent figures. During the last days of New Order reign, they strongly criticized the New Order legacies, like the ideology of developmentalism that promotes urbanization, feudalism, corruption, military-based regime, etc. After the decline of General Suharto, this post-New Order generation actively constructed and shaped Banyumas Film with its distinct aspects of practice and discourse. With anti-New Order slogan, they brought resistance against New Order from street (demonstration) into screen (film). The discussion above unpacks how Dimas Jayasrana used the new film technologies, like video, video projector, internet, pirated software, self-assembled computer, and camera to actualize new ways of resistance. On the other hand, Bowo Leksono strongly criticized New Order's legacies, especially its ideology of developmentalism. With his films, he articulated antidevelopmentalism like anti-urbanization voice and his endless support to promote the marginalized local cultures.

\section{Acknowledgement}

We would like to express our gratitude to Universitas Jenderal Soedirman for funding our research.

\section{References}

Baumgartel, T. (2011). Imagined Communities, Imagined Worlds: Independent Filn from Southeast Asia in the Global Mediascape. Transnational Cinemas, 2.

Clifford, M. (2001). Political Genealogy After Foucault: Savage Identities. New York: Routledge.

Fakih, M. (2016). Analisis Gender dan Transformasi Sosial (Gender Analysis and Social Transformation). Yogyakarta: ISIST.

Heeren, K. V. (2012). Contemporary Indonesian Film: Spirits of Reform and Ghosts from Past. Leiden: KITLV Press.

Irawan, B. (1999). Film, Ideology, dan Militer: Hegemoni Militer dalam Sinema Indonesia. Yogyakarta: Media Pressindo.

Jayasrana, D. (2001). Kepada Yang Terhormat Titik 2 (To The Esteemed).

Kasting Terbuka di Purbalingga. (2005, Agustus 4). Suara Merdeka. Semarang, Central java, Indonesia: Suara Merdeka.

Leksono, B. (2004). Peronika.

Leksono, B (2005a). Gajian (Payday) [Motion Picture].

Leksono, B. (2005b). Senyum Lasminah (Lasminah's Smile) [Motion Picture].

Nugroho, G., \& Herlyna, D. (2015). Krisis dan Paradoks Film Indonesia. Jakarta: Penerbit Buku Kompas.

Prakosa, G. (2005). Film Pendek Independen dalam Penilaian. Jakarta: Komite Film Dewan Kesenian Jakarta \& Yayasan Seni Visual Indonesia.

Prakoso, G. (2001). Ketika Film Pendek Bersosialisasi. Jakarta: Yayasan Layar Putih. 
Yusuf, W. (2014, April 13). CLC Purbalingga: Edukasi Film, Edukasi Politik. Retrieved from http://www.cinemapoetica.com . (2006, July 10). Pergelaran CLC Terbentur Birokrasi. Suara Merdeka. . (2005, June 22). Peronika Masuk Nominasi Giff Award. Radar Banyumas. .(2005, December 8). 'Senyum Lasminah' dari purbalingga Ikut FFI. Suara Merdeka. 